\title{
A GAZDASÁGI FELSŐOKTATÁS HATÁSA A FIATALOK PÉNZÜGYI KULTÚRÁJÁRA
}

\author{
Pintye Alexandra - Kiss Marietta
}

\begin{abstract}
Absztrakt: Kutatásunk célja annak feltárása volt, hogy a célzott pénzügyi-gazdasági képzésben részesülő egyetemi hallgatók pénzügyi kultúrája mutat-e eltérést az ilyen képzésben nem részesülő fiatalokéhoz képest. Eredményeink szerint a gazdasági felsőoktatás pozitív hatását csupán a pénzügyi kultúra egy komponensénél, a pénzügyi ismereteknél lehet egyértelmủen kimutatni. A pénzügyi viselkedés (2. komponens) esetén csupán két elem mentén mutattuk ki a gazdasági képzésben való részvétel pozitív hatását, míg a pénzügyi attitüdök (3. komponens) esetében egyáltalán nem tapasztaltuk azt. Mindez alátámasztja a pénzügyi-gazdasági képzés közoktatásba való bevezetésének szükségességét, hiszen az oktatás a későbbiekben már csupán a pénzügyi kultúra látható, felszín feletti részére képes jelentős hatást gyakorolni.
\end{abstract}

\begin{abstract}
The objective of our research was to reveal whether the financial literacy of university students receiving specific financial-economic education differs from that of youths not participating in this kind of higher education. According to our results, the positive impact of economic higher education can be detected clearly only in the case of one component of financial literacy, namely the financial knowledge. In the case of financial behaviour (the second component of financial literacy) positive effect of the participation in economic higher education appeared only in two elements, while in the case of financial attitudes (the third component of financial literacy) it could not be identified at all. All of this confirms the need for launching financial-economic education into the public education, as later on education can only have a significant impact on the visible, above-surface part of financial literacy.
\end{abstract}

Kulcsszavak: pénzügyi kultúra, gazdasági képzés, pénzügyi ismeretek, pénzügyi viselkedés, pénziigyi attitüdök, fiatalok

Keywords: financial literacy, economic education, financial knowledge, financial behaviour, financial attitudes, young people

\section{Bevezetés}

A gazdasági fejlettség és a kultúra között fennálló viszony, ok-okozati kapcsolat már hosszú idők óta a társadalom- és gazdaságkutatók figyelmének középpontjában áll (Bakacsi, 2008). E kutatók elemzéseik során arra a megállapításra jutottak, hogy a modern gazdaság fejlődését meghatározza a kulturális fejlettség (Remsei, 2011).

A gazdasági kultúra a kultúra azon részhalmaza, amely a gazdasági rendszerek, intézmények és szereplők vizsgálatával foglalkozik. Tágabb értelemben annak a feltárását jelenti, hogy „miképpen gondolkodnak és cselekszenek, hogyan viselkednek, milyen szimbólumokat használnak, milyen értékeket, rítusokat és attitüdöket követnek, milyen hagyományokkal és preferenciákkal rendelkeznek a gazdaság intézményi és egyéni szereplöi” (Husz-Szántó, 2011: 8).

\section{A pénzügyi kultúra fogalma és részei}

A gazdasági kultúra részhalmazaként értelmezhető pénzügyi kultúra nem számít újkeletủ fogalomnak (Béres, 2013), jelentöségére azonban csupán a 2008-as pénzügyi-gazdasági válság hívta fel a figyelmet. A válság egyik legfontosabb 
tanulsága ugyanis az, hogy változásra van szükség a pénzügyi kultúra és a fogyasztói szokások terén (Zsótér-Nagy, 2012).

Atkinson és Messy (2012) a pénzügyi kultúrát három jól elkülöníthető alkotóelemre bontotta: a pénzügyi ismeretekre, a pénzügyi viselkedésre, valamint a pénzügyi attitüdökre és preferenciákra. A pénzügyi ismeretek többek között magukba foglalják a pénzügyi termékek, szolgáltatások terén megszerzett informáltságot és a pénzügyi fogalmak (kamatos kamat, infláció, hozam, diverzifikáció) ismeretét, emellett nagyban hozzájárulnak a megfontolt pénzügyi magatartás kialakításához (Atkinson-Messy, 2012; Husz-Szántó, 2011). Atkinson és Messy (2012) szerint a viselkedés a pénzügyi kultúra legfontosabb eleme. Ez az összetevő olyan magatartásformákat tartalmaz, mint a megfontolt vásárlás, az aktív megtakarítás, a háztartási költségvetés készítése vagy a pénzügyi termékek kiválasztása előtti tájékozódás. A szerzők szerint az attitüdök és preferenciák szintén óriási jelentőséggel bírnak. Megmutatják, hogy az egyén hogyan viszonyul a pénzhez vagy az egyes pénzügyi jelenségekhez, mint például a megtakarításokhoz vagy a kockázatokhoz.

A pénzügyi kultúra fent ismertetett három komponense elhelyezhető a Husz és Szántó (2011) által bemutatott ,jéghegy" modellben ( 1 . ábra). A pénzügyi ismeretek képezik a pénzügyi kultúra tudatos, felszín feletti részhalmazát, míg a pénzügyi viselkedés, valamint a pénzügyekkel kapcsolatos attitüdök és preferenciák a pénzügyi kultúra mélyebb, kevésbé jól látható elemeit, azaz a felszín alatti részhalmazt alkotják. Míg a felszín feletti terület feltárása kevesebb gondot okoz a vizsgálódások során, addig a felszín alatti részek megismerése sokkal nehezebb feladatot jelent a kutatók számára (Husz-Szántó, 2011).

\section{1. ábra: A pénzügyi kultúra ,jéghegy" modellje}

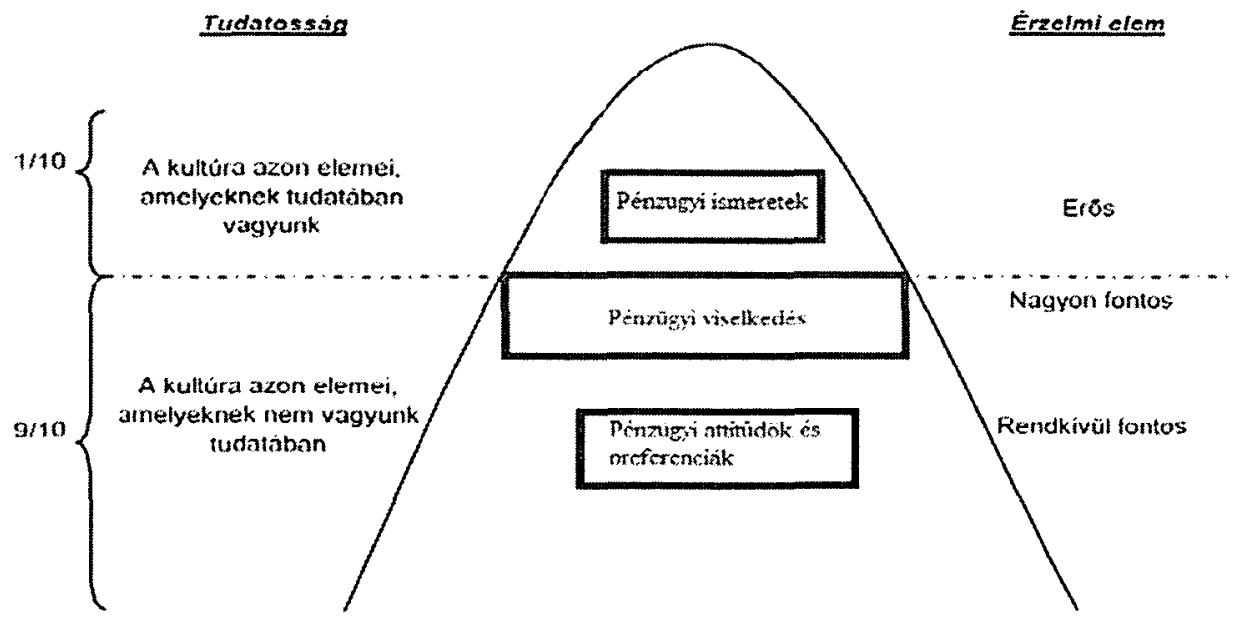

Forrás: A szerzők saját szerkesztése Atkinson-Messy (2012) és Husz-Szántó (2011) alapján 


\subsection{A pénzügyi kultúra fejlesztése}

A pénzügyi kultúra kutatása és mérése mind társadalmi, mind gazdasági szinten jelentős prioritást élvez azokban az államokban, amelyek hatékony pénzügyi képzést szeretnének megvalósítani (Bárczi-Zéman, 2015). A szakirodalomban kitüntetett figyelem jut a fiatal korosztály számára, hiszen pénzügyi döntéseiken keresztül ök nem csupán saját életuikre, hanem a társadalom egészére is képesek jelentős és sok esetben visszafordíthatatlan hatást gyakorolni (Hornyák, 2013a).

Kutatási eredmények (ÁSZ, 2016) támasztják alá, hogy a hazai pénzügyi kultúra fejlődésének egyik gátja lehet, hogy - bár a közoktatásban tanulók jelentős része részt vesz pénzügyi kultúra fejlesztését célzó képzésben - ezek a képzések nagyon rövidek, alig pár órásak. Ez a szükös időkeret pedig gátolja az ismeretek átadásának eredményességét (Várpalotai, 2016). Emellett a fejlesztést célzó képzéseknek nem csupán a pénzügyi ismeretek átadására kell fókuszálniuk, hanem az attitüdöt és a hozzáállást is górcső alá kell venniük, hiszen a pénzügyi tudás szintje szoros kapcsolatban áll a pénzügyek irányába mutatott hozzáállással (Kovács, 2017a). Az elméleti képzés e területen önmagában kevés, a pénzügyi kultúra és ennek komponense, a pénzügyi tudás hatékonyan és maradandóan csak tapasztalati úton sajátíthatóak el (Kovács, 2017b).

A gazdaság valamennyi szereplőjének érdeke, hogy legalább a következö generáció magas szintü pénzügyi kultúrával rendelkezzen. Hornyák (2013b) szerint ez csak úgy valósulhat meg, ha a pénzügyi-gazdasági tantárgy oktatása kötelező jelleggel kerül beépítésre a közoktatásba. Jelenleg a NAT-nak nem része a pénzügyi ismeretek önálló tantárgyként történő oktatása, annak megvalósítását más, meglévő tantárgyak keretében kell megoldani. Kutatási eredményeinkkel azonban alátámasztjuk, hogy bár a pénzügyi edukáció serkentőleg hat a pénzügyi ismeretek szintjére akár a fiatal felnőttek esetén is, a pénzügyi kultúra egyéb elemeinek fejlesztéséhez azonban korábban (már a közoktatásban) el kell kezdeni az oktatását.

\section{Anyag és módszer}

Kutatásunk célja az volt, hogy felmérje a Debreceni Egyetem hallgatóinak pénzügyi kultúráját az OECD által létrehozott három komponens (pénzügyi ismeretek, pénzügyi viselkedés, pénzügyekkel kapcsolatos attitüdök és preferenciák) mentén és ez alapján javaslatot tegyen arra, hogy a pénzügyi kultúra fejlesztését szolgáló eszközöknek mely komponensekre kell kiemelten koncentrálniuk a jövőben. Amennyiben a fiatalok pénzügyi kultúrájának fejlesztését pénzügyi-gazdasági oktatás keretében látjuk megvalósíthatónak, első lépésként érdemes összevetni az ilyen jellegủ szervezett képzésben részt vevő fiatalok pénzügyi kultúráját azokéval, akik ilyen jellegü gazdasági oktatásban nem részesülnek. A kutatási eredményekből ugyanis következtetéseket tudunk levonni arra vonatkozóan, hogy a pénzügyi képzés pozitív hatásai érezhetőek-e a kifejezetten gazdasági képzésben részt vevő fiatalok pénzügyi kultúrájában.

Legfőbb kutatási kérdésünk a fentiek alapján az, hogy a Gazdaságtudományi Karon tanuló, azaz speciálisan pénzügyi-gazdasági képzésben részesülő hallgatók 
pénzügyi kultúrája mutat-e eltérést a további 13 karon tanuló, célzott gazdasági képzésben egyetemi évei alatt nem részesülő fiatal kultúrájához képest. Azaz a gazdasági oktatás, képzés vajon pozitívan befolyásolja-e a hallgatók pénzügyi kultúráját?

\subsection{A minta bemutatása}

Primer kutatásunk célcsoportjául tehát a Debreceni Egyetem hallgatóit választottuk. $\mathrm{Az}$ empirikus vizsgálat adatfelvételét megelőzően készített kutatási tervben célul tüztük ki, hogy valamennyi kar nappali tagozatos hallgatóit - (Állam- és Jogtudományi Kar (ÁJK), Általános Orvostudományi Kar (ÁOK), Bölcsészettudományi Kar (BTK), Egészségügyi Kar (EK), Fogorvostudományi Kar (FOK), Gazdaságtudományi Kar (GTK), Gyermeknevelési és Felnöttképzési Kar (GYFK), Gyógyszerésztudományi Kar (GYTK), Informatikai Kar (IK), Mezőgazdaság-, Élelmiszertudományi és Környezetgazdálkodási Kar (MÉK), Műszaki Kar (MK), Népegészségügyi Kar (NK), Természettudományi és Technológia Kar (TTK), Zenemüvészeti Kar (ZK) - bevonjuk a kérdöíves vizsgálatba.

A hallgatók felkeresésére személyes adatfelvétellel 2016 tavaszán került sor, amelynek eredményeként 1162 nappali tagozatos hallgató által érvényesen kitöltött kérdőívet sikerült begyüjtenünk, majd elemeznünk. 2016. március 15-i adatok alapján a Debreceni Egyetem 20072 nappali tagozatos hallgatójához (DE, 2016) viszonyítva a teljes sokaság 5,79\%-át sikerült lekérdezni.

$\mathrm{Az}$ adatfelvétel során igyekeztïnk valamennyi karon megfelelő számú hallgatót bevonni a felmérésbe, így karonként 100-100 diák megkeresésére törekedtünk. A kitủzött célt a legtöbb kar esetében sikerült tartani, viszont voltak olyan karok, ahol a diákság több helyszín közötti ingázása és a kiscsoportos órák miatt a cél nem valósult meg. A vizsgálat során a legnagyobb gondot a GYTK és a FOK hallgatóinak elérése jelentette, így a megfelelő mintanagyság érdekében e hallgatók pénzügyi kultúráját az ÁOK hallgatóival összevontan „Orvosi képzés” névvel ellátva elemeztük. Hasonló problémába ütköztünk az NK hallgatóinak felkeresése során, így az ő pénzügyi kultúrájukat az EK hallgatóinak pénzügyi kultúrájával összevontan, „Egészségügyi képzés” címkével ellátva ismertetjük.

$\mathrm{Az}$ adatbázis reprezentativitásának vizsgálatát többek között a hallgatók karok szerinti megoszlása mentén végeztük el. A mintában részt vevő hallgatók kar szerinti megoszlását, valamint alapsokasággal történő összehasonlítását az l. táblázat szemlélteti.

Ahogy az a táblázatban is látható, a minta karok szerinti összetétele eltér a Debreceni Egyetem karonkénti hallgatói létszámainak arányaitól, így az nem tekinthető reprezentatívnak. Ennek kiküszöbölése érdekében az adatok elemzése során karok szerinti súlyozást hajtottunk végre.

A kérdőívet kitöltő diákok több mint kétharmada (69\%) nő, annak ellenére, hogy az Emberi Erőforrások Minisztériuma 2012-es oktatási statisztikái szerint közel azonos a magyar felsőoktatásban részt vevő férfiak $(45,1 \%)$ és nők $(54,9 \%)$ aránya (ÁSZ, 2013). A kérdőívet a 19-49 éves felsőoktatásban részt vevő diákok töltötték 
ki. A megkérdezettek jelentős része (95\%) a 19-25 év közötti korosztályba sorolható, míg a kitöltök 4\%-à a 26-30 év közötti korosztályba, $1 \%$ pedig a 30 év feletti korosztályba tartozik.

\section{1. táblázat: A felmérésben részt vevő hallgatók karok szerinti megoszlása}

\begin{tabular}{|l|r|r|r|c|}
\hline \multirow{2}{*}{ Szak } & \multicolumn{2}{c|}{ Sokaság } & \multicolumn{2}{c|}{ Minta } \\
\cline { 2 - 5 } & $\begin{array}{c}\text { Létszám } \\
(f o ̈)\end{array}$ & $\begin{array}{c}\text { Megoszlás } \\
(\%)\end{array}$ & $\begin{array}{c}\text { Létszám } \\
(\text { fö })\end{array}$ & $\begin{array}{c}\text { Megoszlás } \\
(\%)\end{array}$ \\
\hline ÁJK & 951 & 4,74 & 98 & 8,43 \\
\hline$B T K$ & 2410 & 12,01 & 138 & 11,88 \\
\hline$G T K$ & 2705 & 13,47 & 118 & 10,15 \\
\hline$G Y F K$ & 413 & 2,06 & 100 & 7,66 \\
\hline$I K$ & 1382 & 6,89 & 89 & 7,61 \\
\hline$M E ́ K$ & 1399 & 6,97 & 103 & 8,86 \\
\hline$M K$ & 1642 & 8,18 & 95 & 8,16 \\
\hline$T T K$ & 2727 & 13,59 & 108 & 9,14 \\
\hline ZK & 208 & 1,04 & 64 & 5,41 \\
\hline $\begin{array}{l}\text { Egészségügyi képzések } \\
\text { (EK, NK) }\end{array}$ & 1510 & 7,52 & 89 & 7,66 \\
\hline $\begin{array}{l}\text { Orvosi képzések } \\
\text { (ÁOK, FOK, GYTK) }\end{array}$ & 4725 & 23,54 & 160 & 13,77 \\
\hline Összesen & 20072 & 100 & 1162 & 100 \\
\hline
\end{tabular}

Forrás: DE (2016) és saját kutatás alapján

A hallgatók képzési szint szerinti megoszlását vizsgálva megállapítható, hogy a mintában szereplő diákok 67\%-a alapképzésben, 9\%-a mesterképzésben, 20\%-a osztatlan képzésben, $4 \%$-a felsőoktatási szakképzésben vesz részt, míg kevesebb mint 1\%-uk doktori képzésben részesül. A karonkénti megoszláshoz képest a hallgatók képzési szint szerinti összetételében mutatkozó eltérés elenyésző.

A kutatáshoz szükséges adatokat kérdőíves felmérés segítségével gyüjtöttük össze, a nyomtatott kérdőíveket személyesen juttattuk el a hallgatókhoz. Kérdőívünk három nagy blokkból állt össze: bemelegítő kérdések, pénzügyi kultúrát vizsgáló kérdések, valamint demográfiai kérdések. A pénzügyi kultúrát vizsgáló kérdések összeállításánál az OECD által létrehozott hármas felosztást (pénzügyi ismeretek, pénzügyi viselkedés, pénzügyekkel kapcsolatos attitüdök és preferenciák) követtük.

\section{Eredmények és értékelésük}

Kérdőívünk bemelegítő kérdésekkel indult, amelyek közül talán a legfontosabb az egyetemisták vélt pénzügyi tudását hivatott feltérképezni. A diákoknak egytől hétig terjedő Likert-skálán kellett értékelniük, hogy milyen szintünek ítélik saját pénzügyigazdasági ismereteiket. Az eredmények alapján a gazdasági képzésben részt vevő hallgatók önbevallás alapján mért pénzügyi tudásának átlaga a legmagasabb, őket követik a müszaki, illetve informatikai képzésben részt vevők. Ez utóbbi hallgatók 
magas szintủ vélt pénzügyi ismeretei mögött az állhat, hogy a kérdőívet kitöltők között a legnagyobb számban gazdaságinformatikus és müszaki menedzser szakos hallgatók fordultak elö, e hallgatók pedig felsőfokú tanulmányaik során több pénzügyi-gazdasági tárggyal kerülnek kapcsolatba. Mindez alátámasztja, hogy a pénzügyi-gazdasági oktatás növeli a fiatalok pénzügyi magabiztosságát. Welch-féle $d$-próba segítségével megvizsgáltuk, hogy a gazdasági és egyéb képzésben részt vevő egyetemisták vélt pénzügyi ismeretének kategóriaátlagai szignifikánsan eltérnek-e egymástól. Eredményeink szerint a gazdasági felsőoktatásban részt vevők (átlag: 4,420; szórás: 1,006) szignifikánsan magasabbra értékelik $(t=-6,105$; $p<0,001)$ vélt pénzügyi ismereteiket, mint az egyéb képzésben részt vevő társaik (átlag: 3,870; szórás: 1,211).

\subsection{Pénzügyi ismeretek}

A hallgatók pénzügyi ismereteit hat kérdés segítségével teszteltük, ezek egyik fele azt hivatott feltérképezni, hogy az egyetemisták mennyire képesek számolási készségeiket különbözö pénzügyi szituációk során kamatoztatni, míg a kérdések másik fele a mindennapi pénzügyek szempontjából elengedhetetlen fogalmak terén való jártasságot mérte fel.

A pénzügyi témákban való gyakorlati jártasság elemzése során az infláció, a hozamszámítás, valamint a bankszámlanyitás kérdéskörére koncentráltunk. A kérdésekre adott válaszokból egyértelmüen megállapítható, hogy a pénzügyek terén megszerzett elméleti ismereteket leginkább az informatikus hallgatók tudják a gyakorlatban is kamatoztatni. A közgazdász hallgatókat illetően elmondható, hogy az infláció és hozamszámítás gyakorlati alkalmazásának képességét vizsgáló kérdésre adott helyes feleleteik alapján a harmadik, valamint a negyedik helyen állnak a karok közötti rangsorban, míg bankszámlanyitási ismereteik szempontjából az informatikus hallgatók mellett első helyen szerepeltek.

Az elméleti tudást tesztelő kérdésekre adott válaszokat elemezve már egészen eltérö képet kaptunk. A hiteligénylés során oly gyakran felmerülö THM jelentését a ZK hallgatóinak körében ismerték a legtöbben, míg az EBKM ismeretét vizsgáló kérdés leginkább a joghallgatók témában való jártasságát igazolta. Az infláció elméleti ismeretét vizsgáló kérdésre a legtöbb helyes választ a közgazdász hallgatók adták. E hallgatók a THM fogalmának ismeretét szintén bizonyították a vizsgálat során (második helyezést értek el a karok szerinti rangsorban), míg az EBKM jelentéséhez kapcsolódó kérdés gondot okozott számukra (a kérdésre csupán 52\%uk adott helyes választ). A legkevesebb helyes válasz a THM-mel kapcsolatos kérdésre a BTK, az EBKM-mel kapcsolatos kérdésre az MK, az inflációval kapcsolatos kérdésre pedig a ZK diákjaitól érkezett.

A vizsgálat során ellenöriztük, hogy a gazdasági felsőoktatásban való részvétel pozitívan befolyásolja-e a hallgatók pénzügyi tudásának szintjét. A kétmintás $t$ próbák eredményeinek értékelése során arra a megállapításra jutottunk, hogy a felsőoktatásban gazdasági képzésben részt vevők szignifikánsan $(p<0,001 ; t=5,106)$ magasabb pénzügyi-gazdasági ismeretekkel rendelkeznek (1-7-ig terjedő skálán 
átlag: 5,460; szórás: 1,098), mint az egyéb képzésben részt vevők (átlag: 4,910; szórás: 1,282).

$\mathrm{Az}$ egyetemisták pénzügyi ismereteinek szintjéről összességében megállapítható, hogy körükben az egyes pénzügyi fogalmak ismerete, illetve azok gyakorlati alkalmazása sok esetben nem pontos, pénzügyi tájékozottságuk nem teljes körü. A pénzügyi-gazdasági ismeretek szintje sajnálatos módon jó néhány gazdasági felsőoktatásban részt vevő fiatal körében sem mindig bizonyult megfelelőnek. A gazdasági felsőoktatásban és egyéb képzésben részt vevő diákokat összevetve megállapítható, hogy a pénzügyi ismeretek szempontjából a legtájékozottabbak a közgazdász hallgatók, mindez pedig alátámasztja a pénzügyi ismeretek oktatásba való bevezetését, hiszen annak szintje azon diákok körében volt a legmagasabb, akiknek felsőfokú tanulmányaik során lehetőségük adódott ilyen jellegü ismeretek megszerzésére szervezett keretek között.

\subsection{Pénzügyi viselkedés}

A Debreceni Egyetem hallgatóinak pénzügyi viselkedését öt eltéró témában bankszámlanyitás, pénzügyekkel való foglalkozás gyakorisága, megtakarítás, hitelfelvétel, pénzügyi termékek kiválasztása elötti tájékozódás - és különbözö stílusban feltett kérdések segítségével vizsgáltuk.

A hallgatók pénzügyi viselkedésének feltérképezése során az egyik legfontosabb kérdésünk az volt, hogy a diákokat milyen szempontok befolyásolták bankválasztásuk során. A diákok jelentős része (74\%) úgy nyilatkozott, hogy számlanyitását megelőzően szülők, rokonok, ismerősök ajánlâsaira hagyatkozott, azaz ez esetben valószínüleg nem kerülhetett sor a különbözö pénzintézetek ajánlatainak összehasonlítására. A hallgatók számára a második legfontosabb szempont a bank által felszámított díjak mértéke volt, ezt a lehetőséget a megkérdezettek $42 \%$-a választotta, míg a harmadik helyen a bank hírneve, ismertsége áll, amelyet a megkérdezettek $36 \%$-a ítélt fontosnak. A Khi-négyzet próba elvégzését követően arra a megállapításra jutottunk, hogy a bankválasztás és a gazdasági képzésben való részvétel között nincs szignifikáns kapcsolat $(p=0,559$; $\chi^{2}=0,342$ ), azaz a gazdasági képzésben részt vevők a bankválasztás szempontjából nem tekinthetök körültekintőbbnek az egyéb képzésben részt vevő társaikhoz képest.

A pénzügyekkel való foglalkozás gyakoriságának vizsgálata során világossá vált, hogy a fiatalok legnagyobb része, $26 \%$-a csupán havonta többször foglalkozik a pénzügyeivel. Ugyanakkor számos esetben a diákok sokkal tudatosabb magatartást tanúsítottak, hiszen szép számban vannak azok is, akik naponta (22\%), illetve hetente többször (23\%) foglalkoznak a pénzügyeikkel. A pénzügyekkel való foglalkozás gyakorisága és a gazdasági képzésben való részvétel közötti kapcsolat vizsgálata során arra a megállapításra jutottunk, hogy a változók között szignifikáns összefüggés van $\left(p=0,01 ; \chi^{2}=13,253\right)$, a közgazdász hallgatók gyakrabban foglalkoznak pénzügyeikkel, azaz a gazdasági képzésben való részvétel pozitív befolyásoló tényezőként van jelen a pénzügyi viselkedés ezen eleménél.

$\mathrm{Az}$ elemzések során kiderült, hogy a válaszadók $58 \%$-a rendelkezik spórolt pénzzel, míg 42\%-uknak egyáltalán nincs megtakarítása. A megtakarítással 
rendelkező hallgatók arányát karok szerinti bontásban vizsgálva megállapítottuk, hogy az orvosi képzésben részt vevők rendelkeznek a legnagyobb arányban (66\%) spórolt pénzzel, öket követik az informatikus hallgatók (64\%), míg megtakarítás szempontjából harmadik helyen a közgazdász hallgatók (62\%) állnak. A karok szerinti rangsort a joghallgatók, illetve a ZK diákjai zárják, ugyanis e hallgatók csupán 52\%-a vallott arról, hogy van félretett pénze. A megtakarító magatartás elemzése során arra is kitértünk, hogy van-e kapcsolat a gazdasági felsőoktatásban való részvétel és a megtakarítással való rendelkezés között. Az elemzés alapján kijelenthetö, hogy nincs szignifikáns kapcsolat a vizsgált változók között $\left(\chi^{2}=0,342\right.$; $p=0,559$ ), a gazdasági képzés nem befolyásolja pozitívan a hallgatók megtakarító magatartását (a gazdasági felsőoktatásban részt vevők 62\%-a rendelkezik megtakarítással, míg ugyanez az arány a nem gazdasági felsőoktatásban tanulók esetén 58\%).

A továbbiakban azt térképeztük fel, hogy a diákok milyen arányban rendelkeznek hitellel. Az e célból feltett kérdésre egy hallgató nem adott választ, így megállapítható, hogy az 1161 válaszadóból csupán 133 fönek (12\%) van valamilyen hitele, amely az esetek többségében a tanulmányok finanszírozását szolgáló diákhitel. Ez esetben is megvizsgáltuk a hitellel való rendelkezés és a gazdasági felsőoktatásban való részvétel kapcsolatát, a Khi-négyzet próba elvégzését követően azonban nem találtunk szignifikáns kapcsolatot a változók között $\left(\chi^{2}=0,428\right.$, $p=0,513)$. A gazdasági képzésben részt vevő hallgatók közül a hitellel rendelkezők aránya (13\%) tehát nem tér el szignifikánsan az egyéb képzésben részt vevőkétől (11\%). A hitelfelvétel témakörén belül saját kutatásunkban is nagy figyelmet kapott a 2010-es OECD felmérés egyik kulcskérdése, amely azt ellenőrizte, hogy a megkérdezettek vennének-e fel hitelt a mindennapi kiadásaik fedezésére (AtkinsonMessy, 2012). A diákok közül 5\% válaszolt igennel erre a kérdésre, míg jelentős részük, 95\%-uk megalapozott pénzügyi viselkedéséről tanúbizonyságot téve nem venne fel hitelt e célból. A gazdasági felsőoktatásban való részvétel nem befolyásolja pozitívan a diákok ilyen jellegü hitelfelvétellel kapcsolatos döntését $\left(\chi^{2}=0,166\right.$, $p=0,684$ ).

A pénzügyi termékek kiválasztása elötti tájékozódáshoz kapcsolódó kérdésre adott válaszok gyakorisági eloszlását vizsgálva elmondható, hogy a legtöbb hallgató (27\%) hetes skálán mérve ötösre értékeli pénzügyi tájékozódásának mértékét, míg szintén szép számban vannak azok, akik e kérdés esetén négyes (23\%), illetve hatos (20\%) értéket adtak meg. Az egyes értéket, azaz a tájékozódás teljes hiányát kevesen, mindössze a diákok $2 \%$-a választotta, de a maximális tájékozódás sem túl gyakori (13\%) a fiatalok körében. Welch-féle $d$-próba elvégzésével megvizsgáltuk, hogy a gazdasági és az egyéb képzésben részt vevő hallgatók pénzügyi tájékozódásának kategóriaátlagai vajon eltérnek-e egymástól. Az eredmények szerint $(t=3,193$; $p=0,002)$ a gazdasági oktatás pozitívan befolyásolja a pénzügyi tájékozódás mértékét, a GTK hallgatói (1-7-ig terjedö skálán átlag: 5,150; szórás: 1,276) szignifikánsan magasabb szintủ tájékozódást mutattak, mint az egyéb karokon tanulók (átlag: 4,800; szórás: 1,406). 


\subsection{Pénzügyekkel kapcsolatos attitüdök és preferenciák}

A pénzügyi kultúra harmadik részét képező pénzügyi attitüdöt tíz, négy különböző témakört magába foglaló állítás segítségével térképeztük fel. A négy témakör a következő: a pénz időértékével (a megtakarítással), a hitelekkel, illetve a bankokkal kapcsolatos attitüdök, valamint a kockázatvállalási attitüd.

A szükséges elemzések elvégzését megelőzően kódolást hajtottunk végre. Az attitüdökre vonatkozó állítások közül minden negatív állításhoz +3-tól -3-ig terjedő értékeket rendeltünk, azaz +3 pontot kapott az a hallgató, aki egyáltalán nem értett egyet a negatív állításokkal, míg -3 pontot rendeltünk ahhoz a diákhoz, aki teljes mértékben egyetértett azokkal. Ezzel szemben a pozitív állítások esetében az értékek felcserélődtek, azok -3-tól +3-ig terjedtek, -3 pontot kapott tehát az, aki egyáltalán nem értett egyet a pozitív állítással, míg +3 pont járt annak, aki azzal teljes mértékben egyetértett.

A diákok megtakarításokhoz való viszonyát három állítás segítségével mértük, a kódolást követően a három állításra adott válaszok értékének összegeként elöálló Megtakarítási Index (mely -9 és +9 közötti értékeket vehet fel) a hallgatók megtakarításokhoz való szignifikánsan pozitív (átlag: 2,840; szórás: 3,503) hozzáállásáról tanúskodik $(t=-27,648 ; p<0,001)$. A GTK hallgatói Megtakarítási Indexük átlaga alapján a ZK hallgatói előtt, csupán az utolsó elötti helyen állnak. A gazdasági felsőoktatásban és egyéb felsőoktatásban részt vevők Megtakarítási Indexének vizsgálata során arra jutottunk, hogy szignifikáns kapcsolat $(t=-3,526$; $p<0,001)$ van a vizsgált változók kategóriaátlagai között. A gazdasági felsőoktatásban való részvétel ebben az esetben negatív befolyásoló tényezőként értelmezhető, a GTK-n tanulók Megtakarítási Indexének átlaga szignifikánsan alacsonyabb (átlag: 1,960; szórás: 3,361), mint az egyéb képzésben részesülöké (átlag: 2,980, szórás: 3,506).

A következő blokkban a hallgatók hitelekkel kapcsolatos attitüdjeit teszteltük. Szintén három, egy negatív és két pozitív állítás segítségével kellett a diákoknak eldönteniük, hogy a hitelfelvétel számukra elfogadható vagy pedig elutasítják azt. A szükséges elemzések elvégzéséhez a válaszokat ez esetben is kódoltuk, majd a kapott értékeket összesítve a Megtakarítási Indexhez hasonlóan megalkottuk a diákok Hitel Indexét (mely -9 és +9 közötti értékeket vehet fel). A Hitel Index átlaga a hallgatók körében -3,510 (szórás: 2,581), amely egyértelmüen jelzi, hogy inkább elutasítóak a hitelfelvétellel kapcsolatban, semmint egy lehetőségként fognák fel a nagyobb léptékü célok eléréséhez $(t=-46,340 ; p<0,001)$. A hitelekkel kapcsolatos negatív attitúd valamennyi karra egyaránt jellemzö, de értéke a GYFK hallgatónak körében a legjelentősebb, míg a karok közül a ZK esetében tapasztaltuk a legalacsonyabb szintủ elutasítást. A gazdaságtudományi képzésben való részvétel szerint a Hitel Index átlagában nem találtunk különbséget, azaz a gazdasági felsőoktatásban (átlag: -3,590; szórás: 2,513) és egyéb képzésben részt vevők (átlag: -3,500; szórás: 2,592) Hitel Indexének átlagában nincs szignifikáns eltérés $(t=-0,434 ; p=0,664)$.

A diákok bankokkal kapcsolatos attitüdjeinek vizsgálata során arra voltunk kíváncsiak, hogy vajon az egyetemisták mennyire értenek egyet a bankokhoz kapcsolódó negatív, illetve pozitív állításokkal. Az állítások egyenkénti értékelését 
követően összegzésük eredményeként létrejött Bank Index (mely -9 és +9 közötti értékeket vehet fel) alapján elmondható, hogy a hallgatókat a bankokkal szemben kismértékủ szignifikánsan negatív attitủd jellemzi $(t=-9,403 ; p<0,001),-0,880$-as átlagértékkel (szórás: 3,184 ). A kétmintás $t$-próba eredménye, amely a gazdasági képzésben való részvétel és a Bank Index közötti kapcsolatot hivatott vizsgálni, azt jelzi, hogy ez esetben sem lehet szignifikáns kapcsolatot azonosítani a változók között $(t=-0,148 ; p=0,882)$. A gazdasági oktatás tehát nem befolyásolja a hallgatók bankokkal szembeni attitüdjét, mind a közgazdász (átlag: -0,910; szórás: 3,044), mind pedig az egyéb képzésben (átlag: $-0,870$ szórás: 3,207 ) részt vevő diákok kategóriaátlagai a bankokkal kapcsolatos kismértékủ negatív hozzáállást jelzik.

A pénzügyekkel kapcsolatos attitüdök keretében a hallgatók kockázatvállalási hajlandóságát, kockázattal szembeni attitüdjét is megvizsgáltuk. Ez esetben a diákok attitüdjét egyetlen állítás segítségével teszteltuik. A válaszok kódolásával előálló Kockázati Index átlaga (-3-tól +3-ig terjedő skálán átlag: -1,540; szórás: 0,450) szignifikánsan eltér a 0 -tól, azaz a semleges attitüdtől $(t=-34,132 ; p<0,001)$, ami egyértelmüen jelzi a kockázatokkal szembeni negativ hozzáállást. A legminimálisabb kockázatvállalási hajlandósággal a GYFK hallgatói rendelkeznek, míg a kockázatokkal szemben a GTK tanulói bizonyultak a legelfogadóbbaknak. A Kockázati Indexet a képzés típusa függvényében vizsgálva arra jutottunk, hogy szignifikáns $(t=15,186 ; p<0,001)$ eltérés van a gazdasági képzésben és az egyéb képzésben részt vevők Kockázati Indexének átlagai között. A gazdasági képzésben részt vevő diákok jellemzően kockázatvállalóbbak (átlag: 0,050; szórás: 1,430) a hasonló jellegü képzésben nem részesülő társaiknál (átlag: -1,790, szórás: 1,404). Mindez nem feltétlenül értelmezhetö negatívan, hiszen a kockázatvállalási hajlandóság mögött a nem gazdasági képzésben részt vevőkét meghaladó tudásszint is áll.

\section{Következtetések}

Kutatási eredményeink alátámasztják Várpalotai (2016) megállapítását, mely szerint a fiatalok pénzügyi kultúrájának szintje a számtalan fejlesztés ellenére továbbra is hiányos. A vizsgálat azonban rávilágított arra is, hogy a felsőfokú tanulmányaik során pénzügyi-gazdasági képzésben részt vevők vélt pénzügyi ismeretének átlaga (pénzügyi magabiztossága) pozitívan eltér az egyéb képzésben részesülő hallgatók átlagához képest. A hallgatók valós pénzügyi ismereteiről ugyanakkor elmondható, hogy az sajnálatos módon gyakran még a gazdasági képzésben részt vevő diákok esetén is súlyos hiányosságokat mutat, viszont a közgazdász hallgatók szignifikánsan magasabb valós pénzügyi ismeretekkel rendelkeznek az egyéb képzésben részt vevő társaikhoz képest.

A pénzügyi viselkedés vizsgálata során a hallgatók jelentős része nyilatkozott arról, hogy bankszámlanyitását megelözöen szülök, rokonok, barátok ajánlásaira támaszkodott, mindez pedig a tényleges mérlegelés hiányára mutat rá. A gazdasági képzés ezen elemnél nem bizonyult pozitív befolyásoló tényezőnek. A pénzügyekkel való foglalkozás gyakoriságában azonban a gazdasági képzésben való részvétel pozitív irányú eltérést okoz. A megtakarító magatartás vizsgálata során 
megállapítottuk, hogy a diákok valamivel több mint fele rendelkezik megtakarítással. Azok, akik gazdasági képzésben részesülnek, nem rendelkeznek nagyobb arányban megtakarítással, mint az egyéb képzésben részt vevők. Ugyanezt tapasztaltuk a hitelekkel való rendelkezés kapcsán, hiszen sem a hitellel való rendelkezés, sem pedig a mindennapi szükségletek céljából történő hitelfelvétel nem mutatott kapcsolatot a gazdasági felsőoktatásban való részvétellel. A hitelekkel kapcsolatosan összességében pozitív viselkedésmintákat tapasztaltunk, hiszen a hallgatók körében nem jellemző a nagymértékü hitellel való rendelkezés. A pénzügyi termékek kiválasztása előtti tájékozódás mértéke átlag feletti értéket mutat a vizsgált hallgatók körében, a gazdasági képzés pedig pozitívan befolyásolja azt.

A pénzügyekkel kapcsolatos attitüdök és preferenciák vizsgálata során kiderült, hogy a hallgatókat a megtakarításokhoz való pozitív hozzáállás jellemzi, annak ellenére, hogy a pénzügyi viselkedés keretében vizsgált megtakarító magtartásuk egészen mást tükröz. A hitelekkel kapcsolatban a diákok elutasítóak, amelyben talán közrejátszik az, hogy az egyetemistákat a bankokkal szembeni kismértékü bizonytalanság jellemzi, azaz sokan nem hisznek abban, hogy a bankokban tartott pénz biztonságban van, illetve kétlik, hogy a bankok betartják a szerződésben foglaltakat. A kockázatvállalási hajlandóságot tekintve elmondható, hogy a diákok jelentős része kockázatkerülő. A gazdasági képzés befolyásoló hatását vizsgálva csupán a megtakarítással és a kockázattal kapcsolatos attitüd esetén tapasztaltunk eltérést, mégpedig negatív irányban, azaz a gazdasági képzés negatív hatással van a megtakarításokhoz és a kockázatok elkerüléséhez való hozzáállásra. A közgazdász hallgatók tehát az egyéb képzésben részt vevő hallgatóknál jellemzően kockázatvállalóbbak, de e mögött magasabb tudásszint áll.

Kutatásunkkal rávilágítottunk arra, hogy a gazdasági felsőoktatás pozitív hatását csupán a pénzügyi kultúra egy komponensénél, a pénzügyi ismereteknél lehet egyértelmüen kimutatni. A pénzügyi viselkedésnek csupán két eleme mentén mutattak pozitív eltérést a közgazdász hallgatók, míg a pénzügyi attitüdök komponens esetében számottevő (pozitív) hatását nem tapasztaltuk a gazdasági képzésben való részvételnek. Mindez pedig alátámasztja a pénzügyi-gazdasági képzés közoktatásba való bevezetésének szükségességét, mégpedig Kovács (2017a) és Kovács (2017b) javaslatával összhangban a pénzügyi ismereteken túl hangsúlyozottan a pénzügyi viselkedést és attitüdöket célzó fejlesztésekkel. A fiatalok pénzügyi képzését már nagyon korán, az általános (majd közép-) iskolás. évek alatt érdemes megvalósítani, hiszen úgy tünik, hogy az oktatás a későbbiekben már csupán a pénzügyi kultúra látható, felszín feletti részére képes jelentős hatást gyakorolni. Tehát ahhoz, hogy a gazdasági oktatás a mélyebb rétegekben (a viselkedés és az attitüdök szintjén) is kifejthesse pozitiv hatását, már egészen korán hozzá kell látnunk a fiatalok tudatos fogyasztókká történő neveléséhez.

\section{Irodalomjegyzék}

ÁSZ (2013): Felmérés a felsőoktatásban tanulók pénzügyi kultúrájáról. Kutatási jelentés, az Állami Számvevöszék honlapja. $<$ https://www.asz.hu/storage/files/ files/Szakmai\%20kutat\%C3\%A1s/2013/t353.pdf?ctid=743>. (2016.09.28.) 
ÁSZ (2016): Pénzügyi kultúra fejlesztési programok felmérése. Kutatási jelentés, az Állami Számvevöszék honlapja. $\quad<$ https://www.asz.hu/storage/files/files /Publikaciok/Elemzesek_tanulmanyok/2016/penzugyi_kult_fejl_programok.pdf?download=tru e>. (2016.05.18.)

Atkinson, A., Messy, F. (2012): Measuring Financial Literacy: Results of the OECD/International Network on Financial Education (INFE) Pilot Study. OECD Working Papers on Finance, Insurance and Private Pension, No. 15, OECD Publishing. <http://www.oecdilibrary.org/docserver/download

15k9csfs90fr4.pdf?expires=1474549195\&id=id\&accname=guest\&checksum=7F88CB8410899 56FC7C6E8966FC78BE1>. (2016.09.22.)

Bakacsi Gy. (2008): Gazda(g)ság és kultúra - a jövõorientált versenyképesség kulturális meghatározottsága (a GLOBE kutatás alapján). Kutatási beszámoló. <http://real.mtak.hu/1618/I/46897_ZJl.pdf>. (2014.03.19.)

Bárczi J., Zéman Z. (2015): A pénzügyi kultúra és annak anomáliái. Polgári Szemle, 11 (1-3): $\langle$ http://www.polgariszemle.hu/?view=v_article\&ID=659>. (2016. 08. 15.)

Béres D. (2013): A pénzügyi kultúra - $\mathrm{Mi}$ is ez valójában? Pénzügyi Szemle Online, 〈http://www.penzugyiszemle.hu/vitaforum/a-penzugyi-kultura-mi-is-ez-valojaban〉. (2016.09.27.)

DE (2016): A Debreceni Egyetem hallgatóinak 2016. március 15-i létszámadatai képzési szintek szerint. A Debreceni Egyetem honlapja. <http://madhatter.it.unideb.hu/portal/displayDocument/Dokumentumt\%C3\%A1r/Statisztik\%C3\%Alk/Hall gat\%C3\%B3i/2015/2016.\%20tan\%C3\%A9v/A\%20Debreceni\%20Egyetem\%20hallgat\%C3\% B3inak\%202016.\%20m\%C3\%Alrcius\%2015i\%201\%C3\%A9tsz\%C3\%A1madatai\%20k\%C3\%A9pz\%C3\%A9si\%20szintek\%20szerint.pdf> . (2016.10.29.)

Hornyák A. (2013a): Pénz, pénz, pénz, avagy a fiatalok pénzügyi kultúrája. Képzés és Gyakorlat, 11 (1-4): $35-40$.

Hornyák A. (2013b): Pénzügyi kultúra és gazdasági oktatás. Ez lehet a megoldás? Educatio, 22 (1): $89-95$.

Husz I. - Szántó Z. (2011): Mi a pénzügyi kultúra? In: Czakó Á. - Husz I. - Szántó Z. (szerk.): Meddig nyújtózkodjunk? A magyar vállalkozások pénzügyi kultúrájának változása a válság idöszakában. BCE Innovációs Központ Nonprofit Kft., Budapest, 7-12.

Kovács L. (2017b): A pénzügyi kultúra fejlesztése, mint önérdek. In: Pál Zs. (szerk.): A pénzügyi kultúra aktuális kérdései, különös tekintettel a banki szolgáltatásokra. A közgazdaságtanimódszerteni képzés fejlesztéséért Alapítvány, Miskolc. 7-16.

Kovács P. (2017a): Fiatalok pénzügyi kultúra mérésének fejlesztésének lehetőségei. In: Pál Zs. (szerk.): A pénzügyi kultúra aktuális kérdései, különös tekintettel a banki szolgáltatásokra. A közgazdaságtani-módszerteni képzés fejlesztéséért Alapítvány, Miskolc, 31-37.

Remsei S. (2011): Kölcsönhatásban: Gazdaság és kultúra. Kultúra és Közösség, 2 (2): 121-125.

Várpalotai V. (2016): Hogyan lehetnének eredményesebbek a pénzügyi kultúra fejlesztését célzó képzések? Pénzügyi Szemle Online, <http://www.penzugyiszemle.hu/tanulmanyokeloadasok/hogyan-lehetnenek-eredmenyesebbek-a-penzugyi-kultura-fejleszteset-celzokepzesek>. (2016.05.20.)

Zsótér B. - Nagy P. (2012): Mindennapi érzelmeink és pénzügyeink - A pénzzel kapcsolatos attitüdök és a materiális irányultság szerepe a pénzügyi kultúra fejlesztésében. Pénzügyi Szemle, 57 (3): $310-321$. 